\title{
Diasporic Consciousness in Jhumpa Lahiri's The Namesake
}

\author{
Dr. Durgesh Nautiyal \\ Assistant Professor \\ Agastyamuni Degree College \\ Uttarakhand, India \\ durgesh.nautiyal2010@gmail.com
}

\begin{abstract}
The term Diaspora has multiple layers of meaning in academic circles today. The term primarily used to refer to Jewish dispersion, came to be used to refer to contemporary situations that involve the experiences of migration, expatriate workers, refugees, exiles, immigrants and ethnic communities. The Indian Diaspora can probably be traced to ancient times when Buddhist monks travelled to remote corners of Asia. During the ancient times a large number of Indians migrated to Far East and South East Asia to spread Buddhism. The issues of colonialism and slavery, insider- outsider have posed the most difficult problems in the production of identity particularly for the black and third world people. In this way, the many diasporic-literary energies work today. For example, India, Africa, Canada and the West Indies have distinct diasporic backgrounds through which the respective writers' works echo a variety of issues.
\end{abstract}

Keywords: Diaspora, immigrants, colonialism, Alienation, cultural anxieties.

The Indian Diaspora is a generic term to describe the people who migrated from territories of the republic of India. The situation today is largely the success story of the 
Indian Diasporas in the Silicon Valley and the other professionals mainly settled in the U.K., North America and Europe. As Bhiku Parekh commenting on the nature of Indian Diaspora:

Like the banyan tree, the traditional symbol of the Indian way of life, he spreads out his roots in several soils, drawing nourishment from on when the rest dry up. Far from being homeless, he has several homes, and that is the only way he has increasingly come to feel at home in the world. (Parekh 106)

In the recent years, Indian Diaspora has become a pertinent field of study and research. Indian Diaspora means population outside India, particularly of those who have migrated to foreign lands and in course of time renounced their Indian citizenship. Since times immemorial people of India have been migrating to other countries for various reasons. And the diasporic writings are the records of the experiences of the diasporic communities living in varied socio-cultural settings. The Indian diasporic writing covers every continent and part of the world. As K.T. Sunita point out:

Indian expatriate writers do not write from the position of a distant foreign community, such as the exiled black or West Indian novelists, but their writings reflect the perspective of someone caught between two cultures. (Sunita 82)

There are certain common counter voices in the literary representations of the writers' experiences of the indenture and the new, the Indian Diaspora, and the narratives of the individual writers assume great varieties. Jhumpa Lahiri belongs to that category of Indian Diaspora whose only link with Indian is their origin. Lahiri, one of the second generation immigrants in the USA, acknowledged as one of women writers in Indian English Literature for her Indian themes, is a recent new wave literary artist. She has authored the Pulitzer Prize winning collection of short stories Interpreter of Maladies: Stories of Bengal, Boston and 
Beyond (1999) and the novel The Namesake (2003). Her fiction too reflects this return to the past through memory. Lahiri was born in London, England in 1967. Jhumpa Lahiri belongs to the second generation of Indian immigrants in the United States. She has travelled extensively in India and has keenly observed this postcolonial society as well as the challenges of diaspora abroad. She largely writes about the human condition of Indian diaspora in USA. She can be categorized as a multi-cultural, diasporic post-colonial, and, South Asian woman writer. Jhumpa Lahiri as a second generation expatriate, stands at an interesting border as well as a cross road of culture. She has also expressed the diasporic experiences of her parents. In an interview to R.S Shankar, Lahiri recounts:

These trips to a vast, untruly, fascinating city, so different from the small New England town where I was raised, shaped my perceptions of the world and the people from a very different version to everything I belonged there in some fundamental way, in the ways I did not seem in the United States. (Lahiri 8)

As she grew older she becomes aware that she has inherited a sense of exile from her parents. She never feel at home in India as she didn't grow up here and wasn't part of things in this country. In the Namesakethe concept of diaspora has to be specifically understood as a single educated male deciding to leave his country and to move to another more developed Western country for economic gain. This novel constantly focuses on the contrasting experiences of the two generations of expatriates- Ashoke and Ashima who do not attempt to or are not inclined towards getting Americanised while Gogol and Sonia constantly face the need to belong. As the daughter of an educated couple, Lahiri is able to focus in this novel only on that class of people to which she belongs. She, in an interview, speaks of her own predicament to the following effect:

I felt neither Indian nor American. Like many immigrant offsprings 
I felt intense pressure to be two things, loyal to the old world and

fluent in the new, approved of on either side of the hyphen. Looking

back, I see that this was generally the case. (Lahiri 2006)

So she perceives a lack in the ambience in which she was growing up, and this lack is further reinforced by the generation gap. This diasporic space is not at all free from this dilemma. This is to be clearly distinguished from the early phase of Indian Diaspora of indentured labour as well as the later stage- scale movement of unskilled workers for foreign shores. The novel is the story of two generations of an Indian family and their struggle to acculturate themselves in the west. In the autobiographical novel, The Namesake, Lahiri tells the story of Gogol Ganguli, the American-born son of Ashoke and Ashima Ganguli, who arrive in Massachusetts from Calcutta in the late 1960s. Regarding the self in the text versus the self as text in Asian-American Autobiographies, Rocio G. Davis says:

Asian American autobiographies generally highlight the protagonist's growing comprehension of the meaning or value that society places on questions and attitudes about ethnic differences, historical reconstruction, and the place of their communities in American societies (Davis, 2005).

The novel portrays realistically the experiences of this family, which is sometimes afflicted with a feeling of cultural alienation. The novel narrates the saga of Ganguli family in Calcutta and Boston. Ashoke Ganguli is a doctoral candidate in Electrical Engineering at MIT, USA where he is engaged in, "earning a Ph.D. in Boston, researching in the field of fibre optics" (Lahiri 9). Ashoke's career in America made him a prospective groom in Calcutta. After his marriage Ashoke moved with his wife Ashima to Boston. While he remained busy in career building as an architect, Ashima spent her day's nostalgia in a Boston apartment. As critic hold his views:

Ashima's immigrant experience, the clash of cultures in the United 
States, and her non-acceptance by the American society are the main concerns of the novelist in the projection... .Ashima tends to regard the past with nostalgia and the present American experience as an alienating one. (Kadam 123)

Ashima is always nostalgic of her home and spends her leisure in reading Bengali poems, stories and articles. Pregnancy was a hard time for her for there was no one to soothe her. Motherhood is glorious for a woman but for a migrant in a foreign land, loneliness and strange surroundings nearly kill such feelings. Ashima's loneliness after the birth of her son is realistically portrayed. She wants to go back home where her child will have his doting grandparents as well as a host of relatives:

The loneliness of a woman, all alone in a new city- while the husband is at work all day- is clearly seen in this tentative request of Ashima.

Being alone Ashima spends a lot of her time crying, depressed at the unfamiliarity of everything around her. (Nityanandam103)

After Gogol's birth, she says to Ashoke, “I'm saying I don't want to raise Gogol alone in this country. It's not right. I want to go back" (Lahiri 33). When Ashoke realizes her agony, he himself feels guilty for bringing Ashima into an alien country. It is the painful anguish of diasporic identity and the sense of alienation that Lahiri focuses on in her novel. She yearns for individual identity for herself as well as for her imaginary characters. Culture of naming a new born is a practice in every society. Lahiri also narrates this practice with bicultural implications. According to Indian custom parents feel particularly privileged when the child is given a name by the grandparents and elder members of the family. But in American custom a name is chosen at Baptism or after the name of the family predecessors. The American civil authority is not ready to accept a petname for a baby's discharge, and 
official name is mandatory for discharge. They do not wait for choosing a good name for the identification of the child in the outside world. In Indian perception:

Good names tend to represent dignified and enlightened qualities...

pet names have no such aspirations. Pet names are never recorded

officially, only uttered and remembered. Unlike good names, pet names

are frequently meaningless, deliberately silly, ironic, even onomato-

poeic. (26)

Ashoke appreciates the idea but does not like this tradition of choosing a name which would look ridiculous in India. He would prefer a name given by the grandparents in India. Since this is not immediately possible, he chooses the name of Gogol, the surname of the famous story writer, for his son. In the novel the name becomes a quintessential concern, a never-ending quest for Gogol Ganguli. Gogol is admitted to the school under the name of Nikhil but the principal explains that due to their son's preference, he will be known as Gogol in school. When Gogol's sister is born, the Ganguli's are ready with the name, Sonia or Sonali. Gogol grows up with a name that he detests a name that seems to make him stand apart from the rest of his classmates:

Though substitute teachers at school always pause, looking apologetic when they arrive at his name on his name on the roster, forcing Gogol to call out, before even being summoned, 'that's me', teachers in the school system know not to give it a second thought. After a year or two, the students no longer tease and say 'giggle' or 'gargle'. (Lahiri 67)

Throughout the novel, Gogol is haunted by his name; even when he changes it to. Name provides an identity to an individual and Gogol Ganguli is constantly reminded about the uniqueness of his name, "he hates having to wear a name tag on his sweater...he even 
hates that his name at the bottom of his drawings" (75). On Gogol's $14^{\text {th }}$ birthday his father presents him the book The Short Stories of Nikolai Gogol, but does not tell about the train accident. Later on, his father tells him the truth of him being named so. It has a profound effect on Gogol. And it is this 'namesake' that gives the novel its title, The Namesake. Gogol could not assimilate himself with the American culture. Gogol is convinced that he has to change his name and his parents realize that there is no other way out for Gogol in his predicament. The change of his name seems to alter Gogol's personality because after this his confidence grows and he seems to mingle with the land of his birth. He does not feel an outsider, he loses his self-conscious attitude. When finally Gogol hears his father narrate the story of his experiences of 28 years ago he listens:

Stunned, his eyes fixed on his father's profile... for an instant his father is a stranger, a man who has kept a secret, has survived a tragedy, a man who has kept a secret, has survived a tragedy, a man who is vulnerable, who has suffered in an inconceivable way. (123)

That his father had not revealed all this upsets Gogol terribly and he is ashamed at all his earlier reactions to the name Gogol, "He sits there, still struggling to absorb the information, feeling awkward, oddly ashamed at fault" (124). The identity crisis and the feeling of inbetweenness and belonging nowhere is experienced by Gogol who straddles two cultures and suffers from the loss of roots and social dislocation. Tejinder Kaur rightly observes:

Gogol though having passed through many emotional setbacks because of his bicultural identity, is shown to be feeling dejected, distressed, displaced and lonely in the end not knowing what to do after his dreams, his father's death, his wife's desertion and his mother's impending departure to India, but his desire to settle a home... . (Kaur 41) 
For the second generation, the question of identity is a complicated issue. At home Indian culture and value system are adhered to, while in public the American code of conduct is followed. In the melting pot of The Namesake what stands out is the premature and tragic death of Ashoke Ganguli due to a massive heart attack in Cleveland. After the death of her husband, Ashima decides to spend six months of the year in the year in the U.S.A. and six month in India. In spite of her feeling of displacement, marginality, and a crisis of identity, this move is directed towards finding new ways of adaptation in a new country. Jhumpa Lahiri evokes the layered tensions in the experiences of the first and second generation Indian Americans arising out of their divided affiliations and predilections towards their original and adopted homelands. Her characters act as interpreters both the Indian culture and the culture of United States. Gogol engagement with Moushumi, the daughter of his parents' friends is an attempt to enculturate his Bengali identity even though it ends in failure. This marriage seems like Moushumi's attempt at sort of bridge-building between two cultures:

Gogol's relationships with women seem doomed to failure. If cultural similarities can bind a couple together, Moushumi and Gogol should have fared better but the American way of life makes inroads into the martial life of this Indian couple.(Nityanandam 47)

Gogol is once again alone. He is nonetheless comforted by the fact that Ashoke, prior to his death, finally told his son why he had chosen that name for him. At the end of the novel, Gogol comes to accept his name and picks up a collection of the Russian author's stories that his father had given him as a birthday present many years ago. Alone in an alien land, he continues to struggle to find meaning and faith in the land, which is now his. Gogol is a part of the American way of life. His point of view provides the assimilation that every individual needs if he is to feel at home in an alien land. As an alien land but born in the U.S. Jhumpa Lahiri has probably experienced all the points of view. Lahiri's The Namesake, like 
her Pulitzer prize winning collection of short stories does posit the cultural anxieties and unease of Indian Americans but it also forges ahead an abiding seeking nuanced hybridity and integration in our postcolonial times. According to Aruti Nayar, "brings alive the multiple selves contrasted painstakingly to make sense of the unbroken world that is as much a land of opportunities as it is of conflict and confusion” (Nayar 44). Question of identity has remained a source of conflicts and has led to wars in history. But it is more persistent for those who are grown up in two worlds simultaneously. In short, the novel is about a reference bible of experience for immigrant population of South-East Asian Diaspora. The novel deals with the clashes between the two different worlds that Ganguli family simultaneously inhabits. The world of Bengali immigrants who struggle to integrate into mainstream North American culture while maintaining the customs of their homeland, and the world of Ivy League America into which the Ganguli's try to integrate:

Lahiri's The Namesake, thus viewed, Ashima and Gogol as cultural survivors in America's multicultural milieu. They demonstrate the lives of hybridity, in-betweenness and liminality. It is difficult for them to maintain cultural insularity, and like millions of immigrant Indians they essentials their life in the cultural available of America. (Nayak 147)

Lahiri, on the other hand, lives permanently in the U.S and hence portrays experiences which reflect her own. 


\section{Works Cited}

Lahiri, Jhumpa. "Once in a Lifetime." The New Yorker 8 May 2006. www. Wikipedia. Org.The Namesake. New Delhi: Harper Collins, 2004.

R, Davies. "The Self in the Text versus the Self as Text: Asian American Autobiographical Strategies.” Edinbergh: Edinbergh University Press. 2005.

Rushdie, Salman. Imaginary Homelands. London: Granta, 1991.Kadam, Mansing G. "The Namesake: A Mosaic of Marginality, Alienation, Nostalgia and Beyond." Jhumpa Lahiri: Critical Perspectives. Ed. Nigamanada Das. New Delhi.2008.

Kaur, Tejinendr. "Cultural Dilemmas and Displacements of Immegrants in Jhumpa Lahiri's The Namesake". The Journal of Indian Writing in English. 2004. 41.

Sunita. K. T. "Cross Cultural Dilemmas of Indian Women in Bharati Mukherjee's fiction."The Literature of Indian Diaspora. Ed. A. L. Mcleod. New Delhi: Sterling, 2000.

Jayaram N. Ed. The Indian Diaspora- Dynamics of Migration. New Delhi: Sage Publications,2004.Nityanandam, Indira. Jhumpa Lahiri: The Tale of the Daispora. New Delhi.2005.

Nayar, Aruti. "A Story Told with Sensibility and Subtlety.” The Sunday Tribune. 2003. 44

Nayak, Bhagat. "Contra-acculturation in The Namesake." Jhumpa Lahiri: Critical Perspectives. Ed. Nigamanada Das. New Delhi. 2008. 147. 